\title{
Frequency distribution of dental caries disease among the local community of Harichand
}

\author{
Haroon ${ }^{1}$, Tauseef Ahmad ${ }^{2,}$, Muhammad Khan ${ }^{3}$, Inamullah ${ }^{4}$, Arif Jan ${ }^{5}$, Hui Jin²
}

${ }^{1}$ College of Life Sciences, Northwest University, Xian, China

${ }^{2}$ Department of Epidemiology and Health Statistics, School of Public Health, Southeast University, Nanjing (210009), China

${ }^{3}$ Centre for Human Genetics, Hazara University Mansehra 21300, Khyber Pakhtunkhwa, Islamic Republic of Pakistan

${ }^{4}$ Department of Genetics, Hazara University Mansehra 21300, Khyber Pakhtunkhwa, Islamic Republic of Pakistan

${ }^{5}$ Department of Zoology Shaheed Benazir Bhutto University Sheringal, Dir Upper, Khyber Pakhtunkhwa, Islamic Republic of Pakistan

\section{Correspondence}

Tauseef Ahmad, Department of Epidemiology and Health Statistics, School of Public Health, Southeast University, Nanjing (210009), China

Email: tahmad@seu.edu.cn

\section{History}

- Received: 2019-07-14

- Accepted: 2019-08-16

- Published: 2019-08-21

\section{DOI :}

https://doi.org/10.32508/stdj.v22i3.1704

\section{Check for updates}

\section{Copyright}

(c) VNU-HCM Press. This is an openaccess article distributed under the terms of the Creative Commons Attribution 4.0 International license.

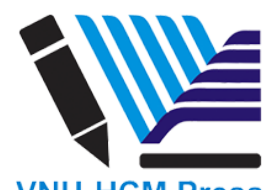

\begin{abstract}
A cross-sectional study was designed to determine the dental caries disease and associated risk factors among the study subjects in Harichand, Pakistan. A total of 150 patients were investigated, of which male to female percentage was $(77 \%)$ and $(23 \%)$ respectively. The maximum tooth decay (33\%) was found in the age (years) of 21-30. The results showed that decayed and missing teeth (DMT) were (57\%), followed by decayed, missing and filled teeth (DMFT) (27\%) and filled teeth (FT) (16\%). Most of the patients were suffering from score 6, (30\%). The DMT and score 6 was recorded high among the study subjects in Harichand. This study will update the epidemiology of dental caries diseases, increase awareness, and provide the base line information for future research and intervention. Further studies are recommended on large scale.
\end{abstract}

Key words: Cross sectional, Dental caries disease, Harichand

\section{INTRODUCTION}

Globally, the prevalence of dental caries diseases is increased day by day, approximately half of the population (age-standardized prevalence: $48.0 \%$ ) suffered disability from oral conditions ${ }^{1}$. In the mouth, bacteria and salivary proteins are present which naturally grow a layer known as biofilm (plaque) on exposed tooth surface. Therefore, if the salivary proteins and bacteria are not removed, their dietary carbohydrates release acid into the biofilm which cause the dental caries. This disease damages the structures of tooth thereby resulting in tooth deterioration which creates holes in the teeth. Therefore, the damages effect on the hard tissue of the teeth (enamel, dentin and cementum). Moreover, they are common continuing transferrable disease resulting from tooth adherent specific bacteria. The destruction of this tissue interrupts which ultimately leads to holes in the teeth ${ }^{2,3}$. Dental treatment is one of the costly health services in the world. Direct treatment costs due to dental diseases globally were estimated 298 billion dollars annually, which corresponds to an average of $4.6 \%$ of total global health expenditure. While indirect costs due to dental diseases amounted to 144 billion dollars annually ${ }^{4}$.

On dental caries disease, very limited work has been carried in the province of Khyber Pakhtunkhwa, Pakistan. Individual health status, families and communities can be improved through quality health services, which protect peoples from financial conse- quences of ill-health. This study was designed to determined dental caries disease and associated risk factors among the local populations of Harichand, District Charsadda, Khyber Pakhtunkhwa, Pakistan.

\section{METHODS AND RESULTS}

The sample size was calculated through $\mathrm{G}^{\star}$ Power software version 3.1.9.2 ${ }^{5}$. The required sample size was projected to be 105 , with effect size $\mathrm{f} 2(\mathrm{~V}), 0.12, \alpha$ error probability 0.01 , and power (1- $\beta$ error probability 0.95$)$. This cross-sectional study was conducted among 150 individuals during July-August, 2015. A specialized performa was designed and validated (by the authors) using the standard procedure, which includes basic information (name, age, address, gender) and disease identification information (gum infection, plaques, flow of saliva). The dental caries disease was identified and recorded according to International Caries Detection and Assessment System (ICDAS) method (Table 1). The following results were recorded accordingly ${ }^{6}$.

In the current study a total of 150 patients were investigated, male to female ratio was 115 (76.67\%) and 35 (23.33\%) respectively. The enrolled patients were divided into six age groups, high number of individuals were in age 21-30 years 50 (33.33\%), followed by 31-40 years 33 (22\%), 11-20 years 25 (16.67\%), 41-50 years $15(10 \%), 1-10$ years $14(9.33 \%)$ and age of above 51 years 13 (8.67\%) (Table 2). The local population of the study area are mainly used the water of wells 98 


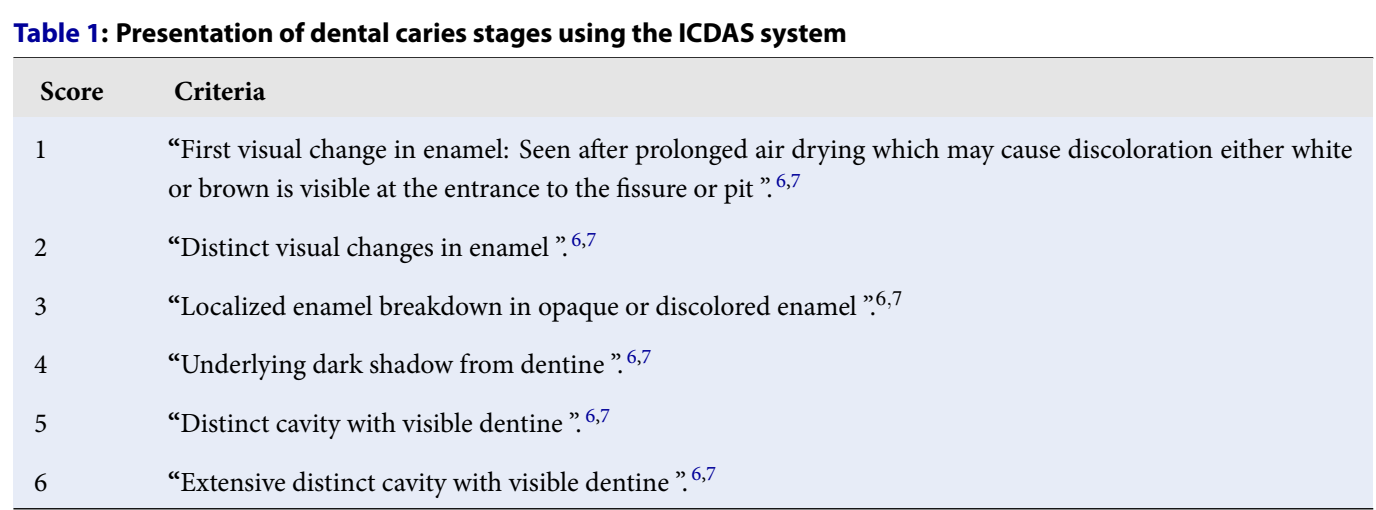

\begin{tabular}{|l|l|l|l|l|l|}
\hline & &
\end{tabular}

Figure 1: ICDAS scoring criteria for studied subjects.

Table 2: Gender and Age wise distribution of enrolled patients

\begin{tabular}{llll}
\hline Variable & Categories & Number & Percentage \\
Gender & Male & 115 & 76.67 \\
& Female & 35 & 23.33 \\
Age & $1-10$ & 14 & 9.33 \\
$11-20$ & 25 & 16.67 \\
$21-30$ & 50 & 33.33 \\
& $31-40$ & 33 & 22 \\
& $41-50$ & 15 & 10 \\
& $>51$ & 13 & 8.67 \\
\hline
\end{tabular}

(65.33\%) for drinking and household purposes, followed by spring water $52(34.67 \%)$. The ratio of soft drink users are 88 (58.67\%). The study area is rich and famous for the sugarcane production, of the total respondent 130 (86.67\%) used sugarcane. DMT were recorded in 85 (56.67\%) subjects, followed by DMFT 40 (26.67\%) and FT 25 (16.66\%). Most of the study subjects were diseased from DMT, which may be due to excessive use of sweets and drinking contaminated water. A study carried out by Dawani et al. ${ }^{7}$ showed that $51 \%$ of the preschool population suffering from dental caries. In addition, another study showed that $61 \%$ of children were suffering from dental caries disease ${ }^{8}$. The study conducted by Ali et al. ${ }^{9}$ reported the overall decayed, missing, filled teeth was $2.49 \%$. For clinical scoring the ICDAS system was used (Figure 1). The score 6 was reported in (65 patients) followed by score 5 (42 patients), score 4 (20 patients), score 3 (11 patients), score 2 (8 patients) and score 1 (4 patients).

Most of the study subjects used dry fruits 75 (50\%), fruits $60(40 \%)$, chocolates $9(6 \%)$ and ice cream 6 (4\%). A total of 112 (74.67\%) individuals used toothpaste for scrubbing of their teeth and 38 (25.33\%) used miswak with irregular use. The study subjects used the hygienic practices (brushing and cleaning teeth per week) 2/7, 37 (24.66\%), 5/7, 78 (52\%) and 7/7, 35 (23.33\%). A study conducted by Sahito et 
al. ${ }^{10}$ reported low prevalence of dental caries disease among the students had brushing habits and belongs to high income families.

\section{CONCLUSIONS}

In conclusion, most of the individuals were suffering from ICDAS score 6 and 5 while the ratio of DMT was found high. The findings of this study are only generalizable to the subjects studied. For risk factors analysis, limited risk factors were included. Awareness regarding dental diseases, oral health education, good hygienic practices, prompt diagnosis and early treatment and many other necessary precautions may help to reduce and control the dental caries disease in the study area.

\section{ACKNOWLEDGMENTS}

The authors are grateful to the local community and doctors for their clinical supports.

\section{AUTHOR'S CONTRIBUTION}

TA and $\mathrm{H}$ : Conceived the idea. $\mathrm{H}$ and TA: Collected the data; wrote the manuscript. MK and I: Critically reviewed the article: AJ and HJ: Helped in technical assistance. TA: Supervised the study.

\section{DISCLAIMER}

None

\section{CONFLICT OF INTEREST}

None

\section{FUNDING SOURCES}

None

\section{ETHICAL APPROVAL}

Ethical approval was granted by the ethical research committee of Hazara University Mansehra, Khyber
Pakhtunkhwa, Pakistan. All the procedures in this study were conducted in accordance with the ethical standard of Hazara University and with the 1964 Helsinki declaration (later amendments or comparable ethical standards).

\section{INFORMED CONSENT}

An informed consent form was signed from the participants included in this study.

\section{REFERENCES}

1. Kassebaum NJ, Smith AGC, Bernabe E, Fleming TD, Reymnolds AE, Vos T, et al. GBD 2015 Oral Health Collaborators. Global, Regional, and National Prevalence, Incidence, and Disability Adjusted Life Years for Oral Conditions for 195 Countries, 1990-2015: A Systematic Analysis for the Global Burden of Diseases, Injuries, and Risk Factors. J Den Res. 2017; 96:380-387.

2. American Academy of Pediatric Dentistry, Policy on Early Childhood Caries (ECC): Classifications, Consequences, and Preventive Strategies. Ref Man. 2014;36:14-15.

3. Scottish Intercollegiate Guidelines Network. Dental interventions to prevent caries in children. Edinburgh: SIGN. (SIGN publication no. 138). 2014. Available from URL: http://www. sign.ac.uk.

4. Listl S, Galloway J, Mossey PA, Marcenes W. Global economic impact of dental diseases. J Den Res. 2015;94:1355-1361.

5. Mayr S, Erdfelder E, Buchnner A, Faul F. A short tutorial of GPwer. TQMP. 2007; 3: 51-59.

6. National Institute of Dental and Craniofacial Research. Dental Caries (Tooth Decay) in Adults (Age 20 to 64). Retrieved September 04, 2018 from https://www.nidcr.nih.gov/researc $\mathrm{h} /$ data-statistics/dental-caries/adults.

7. Dawani N, Nisar N, Khan N, Syed S, Tanweer N. Prevalence and factors related to dental caries among pre-school children of Saddar town, Karachi, Pakistan: a cross-sectional study. BMC Oral Health. 2012; 12:59.

8. Rizvi KF, Bashir R. Oral Health Status in Public School Children. Pak Oral Dental J. 2015;35:649-652.

9. Ali SA, Khan N, Uddin M. Primary and Permanent Dental Caries: Having Differences between Genders? Inter Ped Dent Open Acc. J. 2018;1:1-3.

10. Sahito N, Sahito MA, Fazlani KA. Prevalence of Dental Caries among School Children in Hyderabad Pakistan. Int J Appl SciRes and Rev. 2015;2:1-5. 